\title{
Breaking the Rules: Gamification of Learning and Educational Materials
}

\author{
Carina González ${ }^{1}$ and Manuel Area ${ }^{2}$ \\ ${ }^{1}$ Department of Engineering of Systems and Automatic and Computer Architecture, \\ University of La Laguna, San Cristóbal de La Laguna, Santa Cruz de Tenerife, Spain \\ ${ }^{2}$ Faculty of Education. University of La Laguna, \\ San Cristóbal de La Laguna, Santa Cruz de Tenerife, Spain
}

\begin{abstract}
The printed textbooks and the traditional instruction are in crisis. Some countries already have announced the establishment of educational politics destined to substitute the textbooks by digital educational materials. But, what characteristics should have these new alternative teaching materials to the traditional textbooks?. In this paper we explore the design features to gamify educational materials. So, we explore the mechanics of video games, wondering why games produce "engagement" in his players. Finally, we present a set of properties that can be taken into account as design guidelines for educational gamified materials. This set of properties secure the engagement of educational materials.
\end{abstract}

\section{Introduction}

The massive raid of the ICT (information technologies and Communication) in all the environments and spheres of our company is producing a radical mutation of the forms to produce, to consume, to distribute and to agree to the information and the knowledge. The economic, cultural, and social impact of the omnipresence of the digital technology is very notorious and begins to be so generalized that is transforming what were the rules of up to now existing play in numerous institutions of the knowledge.

To date the schools and the classrooms have been, up to a point, waterproof to the utilization and pedagogical integration of the ICT. It is certain, that a lot of money has been invested and has gifted to the educational centers with classrooms or rooms of data processing and these, in their great majority, already they are connected to Internet of wide band. In many classrooms also there are laptop computers, tubes of multimedia projection and interactive digital shales. Nevertheless, many studies continue showing that the textbooks and other traditional didactic resources continue being the predominant and most habitual media in the practices of classroom. For example, in a recent study carried out in Spain [1] with more than 5,000 educational participants of the Project "School 2,0" (project that continues the politics of the model one 1:1, a computer by student) was found that the textbook continued being the daily technolo- 
gy used of form wholesale number of professors, in spite of the existence of numerous digital technology in its classrooms.

These full situations of contradictions we should interpret them as own phenomena of a time of traffic among the "old school" and the "new school", among the school of the 20th century and that of the 21 st century, among the school of the technology of the role, and the school of the digital technology. The direction or school horizon should advance toward the radical redefinition of the forms and educational goals of the education. In this sense works exist that have explored different possible settings of evolution of the school institution, and in all they, the ICT appear, with greater or smaller importance, as one of the axes or attributes of the future school OCDE [2] [3]. In this sense, reports as the recently published by Fletcher, G.; Schaffhauser, D. and Levin, D. (2012) [4] they fight determined by a school system -in this case for USwithout textbooks in role and full of digital teaching materials.

What characteristic or characteristics should have these new alternative teaching materials to the traditional textbooks? Evidently the first characteristic is that they should be digital, not of role. It implies that the same should assume characteristics as the interactiveness human-machine, the hipertextually or connectivity among some parts and other of the content, multimedia in the sense of the utilization of different languages and expressive forms like the text, the image, the audiovisual thing, the sound, ..., and that they be distributed online.

On the matter, there are two large tendencies or foci of development of this type of digital educational materials:

a) By a part they would be those materials of informational nature that, being digital, they continue being characterized for offering a proposal structured of presentation of the knowledge to the students. Evidently they are interactive, hipertextually, multimedia and online, but they belong to the tradition of the teaching material destined to the presentation or elaborate exposition of the knowledge. This focus has its roots or origin in the CAL (Computer Assisted Learning) and evidently today they adopt new forms as the electronic tablets.

b) The other focus or tendency is the one that proceeds of more next approaches to the constructivism and to the experiential learning. It has their origins in the proposals of S. Papert and they are supported in the logic, interface and playful experiences of the videogames transfers to the educational environment. At present they respond to what is called "gamification of the learning". In the following section we will describe a gamification proposal to create alternative digital educational materials to the traditional textbooks in role.

\section{Gamification Proposal of Digital Educational Materials}

In this section we explore the design features to gamify educational materials. To do this, first of all, we explore the mechanics of video games, wondering why produces "engagement" in their players. Then, we analyze the application of the engagement patterns it in the teaching-learning process. Finally, we present a set of properties that can be taken into account as design guidelines for educational gamified materials. This set of properties secure the engagement of educational materials. 


\subsection{What Can we Learn from Video Games?}

In the most cases of "educational games" -games designed for specific learning purposes-, the learning principles tend to be more focused at practice and exercise than at understanding. This means that the student can memorize the answer to a question that shows many times, but without understanding the underlying rules. Moreover, the knowledge is obtained through the included contents in the game, and the cognitive skills are developed as results of the player actions. On the other hand, most games have a very basic gameplay, often derived from classic games or a simple adventure.

But, ¿what are the differences between a videogame from an educational video game?, ¿which characteristics that make video games so "addictives" ? ihow can incorporate these characteristics into the activities and resources?. In the next, section we propose some main game characteristics and methods for the creation of educational activities.

In "What Videogames have to teach us about learning and literacy", James Paul Gee (2003) [5] maintains that good video games are "machines for learning" since they incorporate some of the most important learning principles postulated by today's cognitive science. Specifically, he states that:

a) Good video games provide the users' information on demand and as needed, not out of context as is often the case in the classroom. It is much more difficult for people to remember or understand information that is given out of context or well before it is needed.

b) Good games are capable of presenting users with tasks that are challenging, but at the same time doable. This is essential to maintaining motivation throughout the learning process.

c) Good games convert their users into creators, and not mere receptors. Their actions influence or build the game's universe.

d) Good games feature initial levels that are specifically designed to provide users with the basic knowledge required to allow them to build generalizations that will enable them to face more complex problems.

e) Good games create a "cycle of mastery", in which players acquire routines through which they increase their level so as to accomplish a specific task. When said task is mastered, the cycle is started again with more difficult tasks.

As a result, many of these characteristics can be used for learning the material and skills relevant to school and professional work.

Moreover, in the design of an educational video game can be considered a set of properties that securing the "learn to play and play to learn", that is named "educational playability". In general terms, "playability" [6] can be defined as: "a set of properties that describe the player experience using a specific game system whose main objective is to provide enjoyment and entertainment when the player plays alone or in company". In extension, the educational playability is not limited to playful objectives but must take into account educational objectives, such as learning while having fun, improving the abilities of students to solve complex problems, reinforcing players' skills and improving player experience [7] (Table 1). 
Table 1. Playability Design Patterns to Facilitate the Design of Educational Video Games [7].

\begin{tabular}{|c|l|}
\hline $\begin{array}{c}\text { Educational Playability } \\
\text { Proprieties }\end{array}$ & \multicolumn{1}{c|}{ Description } \\
\hline Satisfaction & $\begin{array}{l}\text { The gratification or pleasure derived from playing a complete video game or } \\
\text { from some aspect of it }\end{array}$ \\
\hline Learnability & $\begin{array}{l}\text { The player's capacity to understand and master the game system and mechanics } \\
\text { (objectives, rules, how to interact with the video game, etc.). }\end{array}$ \\
\hline Effectiveness & $\begin{array}{l}\text { The resources needed to offer players a new experience -fun and learning- } \\
\text { while they achieve the game's various objectives and reach the final goal. }\end{array}$ \\
\hline Immersion & $\begin{array}{l}\text { The capacity of the contents to be believable, such that the player becomes } \\
\text { directly involved in the virtual game world. }\end{array}$ \\
\hline Motivation & $\begin{array}{l}\text { The set of game characteristics that prompt a player to realize specific actions } \\
\text { and continue undertaking them until they are completed. }\end{array}$ \\
\hline Emotion & $\begin{array}{l}\text { This refers to the player's involuntary impulse in response to the stimulus of the } \\
\text { video game that induces feelings or a chain reaction of automatic behaviors. }\end{array}$ \\
\hline Supportive & $\begin{array}{l}\text { The set of game attributes, elements and resources that promote the social } \\
\text { dimension of the game experience in a group scenario. }\end{array}$ \\
\hline Educative & $\begin{array}{l}\text { The ability of the game to keep the player motivated, to teach players/students } \\
\text { effectively and encourage them to continue learning and achieve the learning } \\
\text { objectives. }\end{array}$ \\
\hline $\begin{array}{l}\text { The educational characteristics of the game and the ability of the player to be } \\
\text { aware of, understand, master and achieve the learning goals }\end{array}$ \\
\hline
\end{tabular}

\subsection{Gamification Proprieties}

Relating to the "addictive" or "engagement" component of games, we can found the "gamification" concept [8]. Essentially, gamification tries to apply the mechanics of the games in other settings, such as the educational environment. This concept is not directly related to game design, but seeks to engage the user through small doses of challenges and rewards in order to get that the user perform certain actions in different environments.

Gamification works to satisfy some of the most fundamental human desires: recognition and reward, status, achievement, competition \& collaboration, selfexpression, and altruism. People are hungry for these things both in their everyday world and online. Gamification taps directly into this.

The game mechanics can be of different types, such as: a) behavioral (focused on human behavior and the human psyche), b) feedback (related with the feedback loop in the game mechanic) and c) progression (used to structure and stretches the accumulation of meaningful skills). In Table 2, we present a proposal of different suggested game mechanics to gamify environments, in our case, educational gamified materials.

There are other game mechanics that can be used for gamification materials and educational activities, such as: time (the players have some limited time to perform a task), exploration (players have to explore and discover things that will surprise them), challenges between/among users (players can challenge each other and compete for the achievement of objectives, objects, medals, etc..).

It is also important to have other people with whom to compete, collaborate and compare accomplishments. As a general rule, humans want to interact and compete with others. In the social game, the objectives can be competitive or collaborative. 
When you get users to compete and collaborate as part of something bigger, it increases the stakes, adds another level of accountability and is a dynamic motivator. So, in team games must be considered separately the mechanics that influencing the team (win projects, group scores, etc.) as well as the mechanic is that influencing the individual (motivation, positive reinforcement, etc..). In a best-practice implementation, a user's individual achievement should be rolled up under the group or team's success and highlighted in inter and intra group leaderboards and news feeds.

Table 2. Proposal of recommended game mechanics to be used in educational materials.

\begin{tabular}{|c|c|}
\hline Game Mechanic & Description \\
\hline Collection & $\begin{array}{l}\text { It exploits the human characteristic of "collector", all are or have been collectors of } \\
\text { something: books, records, pictures, movies, etc. }\end{array}$ \\
\hline Points & $\begin{array}{l}\text { It is the most used mechanical, in real life we handle sports scores, grades in school, } \\
\text { etc.. We reward or punish through the points given or removed, respectively. Points } \\
\text { are a running numerical value for a single action given or a combination of actions. }\end{array}$ \\
\hline $\begin{array}{l}\text { Comparisons and } \\
\text { classifications } \\
\text { (leaderboards) }\end{array}$ & $\begin{array}{l}\text { It exploits the social component, the effort is compared with other users and / or other } \\
\text { types of classifications (global, local, etc..). Leaderboards give users the } \\
\text { feeling of "fame" and "status." They also give users the chance to compete and } \\
\text { compare with other members or players. }\end{array}$ \\
\hline Levels & $\begin{array}{l}\text { The levels are related to the user experience or level of expertise (expert users, be- } \\
\text { ginners, etc..). Karate belts, job titles, and frequent flyer programs are just some of } \\
\text { the examples. They are to shorthand indicator of status in a community and show that } \\
\text { you should be afforded respect for your accomplishments. }\end{array}$ \\
\hline Status & $\begin{array}{l}\text { Status is the ranking or level of a player, related to the scores obtained by users, users } \\
\text { are motivated to achieve a high status. }\end{array}$ \\
\hline Feedback & $\begin{array}{l}\text { People are used to receiving feedback on their actions, it is important to reward } \\
\text { positively and provide information to the user about his condition, the environment, } \\
\text { and their achievements. For example, showing the progression in which the success is } \\
\text { granularity displayed and measured through the process of completing tasks. Or } \\
\text { giving rewards to motivate users: points, badges, trophies, virtual items, unlockable } \\
\text { content, digital goods, etc. }\end{array}$ \\
\hline Achievements & $\begin{array}{l}\text { Achievements are a virtual or physical representation of having accomplished some- } \\
\text { thing, usually considered "locked" until the user have met the series of tasks that are } \\
\text { required to "unlock" the achievement, for example virtual coins, medals or badges. }\end{array}$ \\
\hline Epic meaning & $\begin{array}{l}\text { Players will be highly motivated if they believe they are working to achieve some- } \\
\text { thing great, something awe-inspiring, something bigger than themselves. Examples of } \\
\text { this mechanic applied to education could be, the fight to save the planet while they } \\
\text { are learning about the environmental care. }\end{array}$ \\
\hline
\end{tabular}

The best way to approach this is with a standard ranking system. Once you have identified the actions for environment, system or activity, you will want to rank them in order of value. Start with the least valuable action and give it a factor of ' 1 .' Working from there, assign relative values to everything else.

So, you can use different kinds of point for different purposes and activities, for example: basic points (usually earned by participation and spendable on virtual or physical goods), experience points (earned by participation, constantly increasing and the point total is never deducted, not spendable), premium points (only for some special action, spendable on "premium" virtual or physical goods). Once they reach a set number of points, they progress on to the next designated level. Alternatively, another option is a hybrid approach, mixing points and tasks to allow the users to progress. 
Badges should tie directly into the goals and to what users care about and are proud of. They also encourage exploration of your site, even mastery. Badges can also be used to encourage users to take a specific action. Some badges can be "aspirational," requiring certain prerequisites such as achieving a certain level or owning another badge or virtual good.

Another option is to use the time to reward students based on the made activities, such as:

- Every time - Every time that participating in the forum, the student earn 10 points.

- After X times - After 10 participations, the student get a trophy.

- Score higher than $X$ - Score 90 or more on the quiz, and receive 100 points.

- Time limited - The clock is ticking! Now or never...

Moreover, the gamification of educational resources can be enriched through the use of mobile devices and tablets (smartphones), using geolocation and social networking. These wide possibilities are still uncharted; there is a long way to explore.... why we do not start now?

\section{Conclusions}

The printed textbooks and the traditional instruction are in crisis. Some countries already have announced the establishment of educational politics destined to substitute the textbooks by digital educational materials. For example, the South Korea Department of Education has planned that the tables and other electronic devices will replace the textbooks of role in the year 2014. In U.S.A. various federal states as Florida or California already have begun this process. The State Educational Technology Directors Association (SETDA) demand that this process finish in the course 2017-2018 [3].

Already there are many voices that admit the need and urgency that the school be appropriated of the digital technology and transform of radical way its pedagogical practice. It is time to break the rules in education in schools. Students should learn together, should research and develop projects, must be independent and must use much digital technology [9]. We must go beyond textbooks and traditional teaching that transmits information.

In this paper, we have intended to synthesize two of the most noticeable foci of the digital alternatives to the textbooks: on the one hand, educational digital books that respond to a vision structured of the knowledge, and by another to the gamification of educational material that offer flexible and open experiences of learning supported in the contributions of the videogames. Our position is not to defend in exclusive a focus or another, but to present the need that in the school of the 21st century both types of materials live together. The presence and use of these different technologies (structured digital contents and gamification material) will provide the students so much varied learning to formal teaching processes bias as of playful and more informal experiences. 


\section{References}

1. Area, M. (Dir) (2011): ¿Qué opina el profesorado sobre el Programa Escuela 2.0? Un análisis por comunidades autónomas. Avance preliminar de resultados. Available in: http://ntic.educacion.es/w3//3congresoe20/Informe_Escuela20-Prof2011.pdf 15/09/2012.

2. OCDE (2001): Schooling for Tomorrow. What Schools for the Future?. Centre for Educational Research and Innovation (CERI), Paris.

3. OCDE (2009): Beyond Textbooks: Digital Learning Resources as Systemic Innovation in the Nordic Countries. Centre for Educational Research and Innovation, Paris. Available in: http://www.keepeek.com/Digital-Asset-Management/oecd/education/beyond-textbooks 9789264067813-en 3/10/2012.

4. Fletcher, G.; Schaffhauser, D. y Levin, D. (2012): Out of print: Reimagining the K-12 textbook in digital age. SETDA, Stte Educational Technology Directors Association, Washington, D.C.

5. Gee, J. P. (2003). What Digital Games Have to Teach Us. About Learning and Literacy. New York \& Basingstoke: Palgrave Macmillan.

6. González Sánchez, J. L. (2010). Jugabilidad. Caracterización de la experiencia del jugador en videojuegos. Tesis Doctoral. Universidad de Granada. Available on the Dialnet database.

7. Ibrahim A., Gutiérrez-Vela F., Padilla-Zea, N., González-Sánchez, J.L. (2012). Playability Design Patterns: An Approach to Facilitate the Design of Educational Video Games. Student Usability in Educational Software and Games: Improving Experiences. DOI: 10.4018/978-1-4666-1987-6.ch005. pp 118-136. IGI Global Ed. USA.

8. Zichermann, G. \& Cunningham, C. (2011). Gamification by Design: Implementing Game Mechanics in Web and Mobile Apps. O'Reilly Media, Inc. USA.

9. Titlow, J. P. (2012). How iPad is changing education, ReadWriteWeb. Retrieved October, 5, 2012, Available on: http://www.readwriteweb.com/archives/ how_the_ipad_is_changing_education.php. 